\title{
Intellectual property rights
}

\section{The patent system and the dynamics of innovation in Europe}

\section{Dominique Foray}

\begin{abstract}
After briefly examining the US challenge and the international and European dimensions of patent regulations, this paper devotes special attention to the short-term and long-term issues facing the European patent system. The concluding remarks reflect upon the problems and possible solutions identified in the article and discuss the role of the patent system in relation to the dynamics of innovation in Europe.
\end{abstract}

Professeur Dominique Foray is Chaire Economie et Management de l'Innovation, Collège du Management, Bât ODYSSEA, Swiss Federal Institute of Technology (EPFL), CH - 1015 Lausanne, Switzerland; Tel: +41 2169300 35; Fax: +41 21693 24 89; E-mail: dominique.foray@epfl.ch.

The author is grateful for the good advice of the SEGERA team, and particularly Susana Borrás for her useful comments, encouragement and patience.
7 DEE ECONOMIC IMPORTANCE of intellectual property has been rising spectacularly over the past decades, as its value is increasing as a share of average total firm value. The number of patent applications is growing at double-digit rates in the major patent offices, and licensing and cross-licensing are being employed with greater frequency than ever before, particularly in hightechnology industries. The increased intensity of innovation characterising the knowledge-based economy and the increase in the propensity to patent (that is, the increase in the ratio of number of patents to number of innovations or number of patents per real $R \& D$ spending) that is indicative of the emergence of new research and innovation management techniques are the main factors contributing to this quantitative evolution.

Although patents and other intellectual property rights (IPR) are becoming of great importance to support innovation and economic growth, their impact on economic performance is extremely unbalanced and uneven in different countries and national systems of innovation. In this article, we reiterate that this impact is very weak in Europe and that there is, therefore, significant room for policy action to create a better system of IPR, which constitutes one of the key institutions in systems of innovation.

After briefly examining the US challenge and the international and European dimensions of patent regulations, this paper devotes special attention to the short-term and long-term issues facing the European patent system. The concluding remarks reflect on the problems and possible solutions identified in the article and discuss the role of the patent system for the dynamics of innovation in Europe. 
Dominique Foray is Professor at the Swiss Federal Institute of Technology in Lausanne where he hold the Chair of Economics and Management of Innovation. He serves as Dean of the Collège of Management. His research interests include all topics and issues related to the economics and management of technology, knowledge and innovation at both micro and macro levels. He is recognised as one of the leading academic experts on the economics of innovation and knowledge, and the economic policy implications of the new knowledge-based economy.

\section{US challenge}

Table 1 provides information concerning the patent propensity rates for large European and American firms, as a proxy of patent rates for Europe and America (that is, of all patentable innovations, the number actually patented). It indicates that European firms patent less than American ones. The reasons for such a weak propensity to patent in Europe are clearly identified thanks to the Community Innovation Survey (CIS): the main reasons in the case of large firms are that patents are not considered to be particularly effective for preventing imitation, and the patent application process itself may provide too much information to rivals. These two reasons are cited by approximately $60 \%$ of CIS respondents that chose not to patent an innovation, compared to $26 \%$ citing application cost and $13 \%$ defence costs as the principal reason (MERIT, 2000).

At the same time, American companies are developing aggressive patent strategies in the USA and Europe, by means of patent extension to the European Patent Office (EPO), while the American legal framework has been greatly upgraded. The creation of intellectual property becomes a central objective in the global strategy of large American firms.

For a long time, the approach to intellectual property was that patents were for defensive purposes only; patents and related know-how ought not to be sold. Licensing represented a drain on internal resources. Patents are now regarded as unique means by which to generate value from intangible assets, and companies are starting to exploit this through aggressive licensing programmes. Thus, Arora et al (1999) note with regard to DuPont, "Reversing its tradition of treating in-house technology as the jewel of the crown, DuPont has started to exploit it through an aggressive licensing program".

Table 1. Patent propensity in Europe and the USA

\begin{tabular}{lcc}
\hline & $\begin{array}{c}\text { Product } \\
\text { innovations (\%) }\end{array}$ & $\begin{array}{c}\text { Process } \\
\text { innovations (\%) }\end{array}$ \\
Europe & 44 & 26 \\
United States & 52 & 44 \\
\hline
\end{tabular}

Source: MERIT (2000)
With the current (or expected) strengthening of national and international legal systems of intellectual property, the expected benefits of amassing portfolios of legal rights began to outweigh their costs. Hall and Ziedonis (2001) explain the patent paradox in the semiconductor industry, that is, the gap between the relative effectiveness of patents and their widespread use, with the fact that large companies amass vast patent portfolios simply as "bargaining chips" to allow them to sort out conflicting and overlapping claims to intellectual property.

The other complementary evolution in the USA is changes in patenting policy as it is implemented by the patent office. This includes: the expansion of patentable subject matter to include software, business methods and gene fragments; an apparent reduction of the size of inventive step required (especially in some of the new subject matter areas); inadequate prior art search, ${ }^{1}$ again especially in new subject matter areas; and excessive claims breadth.

The main aspect of changes covering all these evolutions is that patent offices have completely surrendered their regulatory role. Until the 1970s, the general view held by them was that patents were anti-competitive and detrimental for the economy. Patent offices were predominantly regarded as 'rejection offices' rather than as institutions for supporting innovators. They therefore played a significant regulatory role, blocking or slowing down private appropriation in certain fields. For example, the patentability criteria of 'industrial application' (utility) were very effective in the USA in blocking the patenting of the first genetic inventions in the late 1980s.

For several reasons, patent offices have become extremely pro-patent since the early 1980s. The new view is that innovation must be assisted and foreign investors attracted. The applicant, formerly considered with suspicion, has become a 'client', whose needs must be satisfied by quick, cheap procedures. The result is a total deterioration of examination procedures, as the office's role is confined to that of a registry office and a statistics bureau.

Thus, the pendulum started swinging away from rigorous examination towards expediency, both in terms of time and money. Nowadays, patentability

\section{US patent offices have become extremely pro-patent since the early 1980s: innovation must be assisted and foreign investors attracted, with a resulting deterioration of examination procedures, as the office is confined to a registry office and statistics bureau}


criteria have ceased to play their role of preserving the public domain; the criteria have gradually been eased and extended to new subject domains. Many research results have now become patentable as a result of both legal (court) and patent office decisions. The increasing opportunity to patent fundamental knowledge, research tools and databases is part and parcel of a broader movement towards strengthening IPRs.

The third evolution deals with the transformation of the US legal system. This involved the creation of the Court of Appeals for the Federal Circuit. It was established to unify the basis of interpretation and enhance firms' confidence by reducing legal uncertainty (Jaffe, 2000). A range of other factors in the institutional environment in the USA is reinforcing this trend in favour of the applicant, for example, the evolution of the judicial institution and jurisprudence, which are increasingly favourable towards the patent holder as opposed to a party suspected of infringement. In the USA, where only $62 \%$ of holders of valid patents won their appeal case before 1980, this figure has risen to $90 \%$ (Jaffe, 2000).

These results ought to incite us to turn to the nature of the patent system in Europe as well as of the legal framework providing the necessary tools to enforce property rights.

\section{Policy issues at nationally and internationally}

At the national level, the benefits and costs of stronger intellectual property (IP) protection are at least conceptually simple: stronger IP rights provide stronger incentives for innovators and increase the potential for local (within country) spillovers from $\mathrm{R} \& \mathrm{D}$. The costs are higher prices because of the monopoly power thus created and an increase in the cost of follow-on innovation, which may reduce local R\&D by increasing transaction and other costs of acquiring prior knowledge. Choosing an optimal national policy depends on weighing these costs and benefits (Hall, 2001).

As is explained well by Hall (2001), the implications of national policies at international level are more difficult to analyse. One problem arises because the very externalities leading a country to adopt IP protection policy mean that the effects of the policy do not stop at the national border, nor are countries immune from repercussions from the policies of other countries. A country with a strong IP policy has increased the global incentives for innovation and the potential for spillovers, while at the same time reducing the relative incentive for innovative activity elsewhere, both by attracting R\&D to move within its borders and by raising the cost of followon invention elsewhere.

Of course, the actual size of these cross-border effects varies enormously with a country's size, capacity for innovation and $R \& D$, education levels, trade position and even commercial language. Countries where business is conducted in English are privileged because of the prominence of that language in international patenting and scientific publication. Such factors mean that countries such as the USA will be less impacted by developments elsewhere than will smaller economies. The optimal national policy that takes account of international consideration may therefore be quite different in different countries. Nevertheless, the collective view expressed in the TRIPS (trade-related aspects of intellectual property rights) agreement is that harmonisation in intellectual property protection is desirable.

However, we should make a critical note of the tendency of harmonisation to raise the level of protection. Once a property right has been granted, it is extremely difficult to subsequently take it away, which means it is far easier politically to strengthen IPR in countries where it is weak than to weaken it in countries where it is strong.

\section{Short-term policy issues}

A strong patent system is characterised by a high degree of confidence of agents in this way to gain protection from imitators. The conditions rendering a patent system 'strong' concern enforcement, minimum level of legal uncertainty, minimal probability of litigation, and low application costs. This means that the system, as it stands in Europe and beyond at present, is not 'strong' at all; it is weak.

Reinforcing the protection of intellectual property, which is a matter of institutional and legal adjustments (in the sense of unifying patent doctrine to minimise ambiguities and uncertainties in patent suits or reduce the cost of patent application or improve enforcement conditions), is, thus, a priority at both the European and international levels.

At the global economic level, the TRIPS agreements oblige all World Trade Organisation (WTO) members to establish a minimum level of legislation in favour of intellectual property rights; however, the costs of upgrading the intellectual property system and increasing its quality (including, for instance, the training of patent personnel and the improvement of facilities in the intellectual property administration) are so high that a transition period has been organised for many developing countries.

The European Patent Convention (EPC) and its patent office ensure that the procedures for applying for, and granting, patents in Europe are the same throughout its 27 member countries. This provides considerable procedural harmonisation among European countries; however, these rights must be defended in each individual country. The ensuing high levels of legal uncertainty thus render the current European patent system 'weak'. Furthermore, filing a patent in Europe is a costly activity (actually more costly than in the USA or Japan). Table 2 presents a comparison of costs and fees, in Euros, for the three big patent systems. 


\begin{tabular}{lccccccc}
\hline & $\begin{array}{c}\text { Filing/ } \\
\text { search fees }\end{array}$ & $\begin{array}{c}\text { Examination } \\
\text { fees }\end{array}$ & Grant fees & Renewal fees & $\begin{array}{c}\text { Translation } \\
\text { costs }\end{array}$ & Agent fees & Total \\
EPC & $810+532$ & 1431 & 715 & 16790 & 17000 & 12600 & 49900 \\
USA & 690 & - & 1210 & 2730 & na & 5700 & 10330 \\
Japan & 210 & 1100 & 850 & 5840 & na & 8450 & 16450 \\
\hline
\end{tabular}

Source: Horward (2002)

It is important to note the right hand column, which indicates the comparison between the overall costs involved in the current European system, the USA and Japan. It shows that the average cost of obtaining a European patent is considerably higher than in the case of our competitors. We can see that translation costs and renewal fees are highly significant factors in the difference among the systems.

As regards translation costs, there are broad differences among the three scenarios evaluated:

- Complete translation of the patent document into the ten official languages: 17,000

- Translation of the patent document into the three working languages of the Office: 5100

- Translation of the patent document into one of the Office's three working languages and of the claims into the other two: 2200

Efforts to create a true 'European Community' patent that could be enforced uniformly in the 25 countries were relaunched in the late 1990s; however, in spite of these efforts and widespread demand for such an instrument from European business, a final decision has not been reached at the time of writing. There are two primary political problems associated with the creation of a Community patent: the adjustment of national court systems in Member States; and the language regime. In 2003, progress was made towards reaching a 'common position' at the ministerial level, agreeing to a single, specialised Community Court and to establish a linguistic regime capable of maintaining translation costs at a minimum.

\section{Long-term policy issues}

From 1836 to 1950, there were just under 2.5 million patents issued in the USA. In 1999 alone, the USPTO (US Patent and Trademark Office) received 270,000 applications and issued more than 150,000 patents, one of which bore number 6,000,000 (Pooley, 2002). In 2000, the number of applications reached 300,000 for the first time. Over the past ten years, American patent applications and patent grants have thus both increased at a rate of about $6 \%$ per annum, compared to about $1 \%$ per annum in the preceding 40 years.

In Europe, similar effects are observed, with EPO applications rising at an annual rate of $10 \%$ per annum over the past five years. Interestingly, the response of the EPO, unlike the USPTO, has been to maintain a steady grant rate, meaning that the application-grant lag has risen (see Figures 1 and 2).

A series of problems appear to emerge in the long term.

Increasing transactions costs This view entails a large set of implications involving various phenomena that can be grouped, for the sake of convenience, under the heading "transaction cost increases". Both qualitative trends (increasing fragility of patents) and quantitative changes (increase in the number of patent applications and grants) are likely to increase transaction costs.

Efforts and costs devoted to sorting out conflicting and overlapping claims to IPR will increase, as will uncertainty regarding the nature and extent of legal liability in using knowledge inputs. Again,

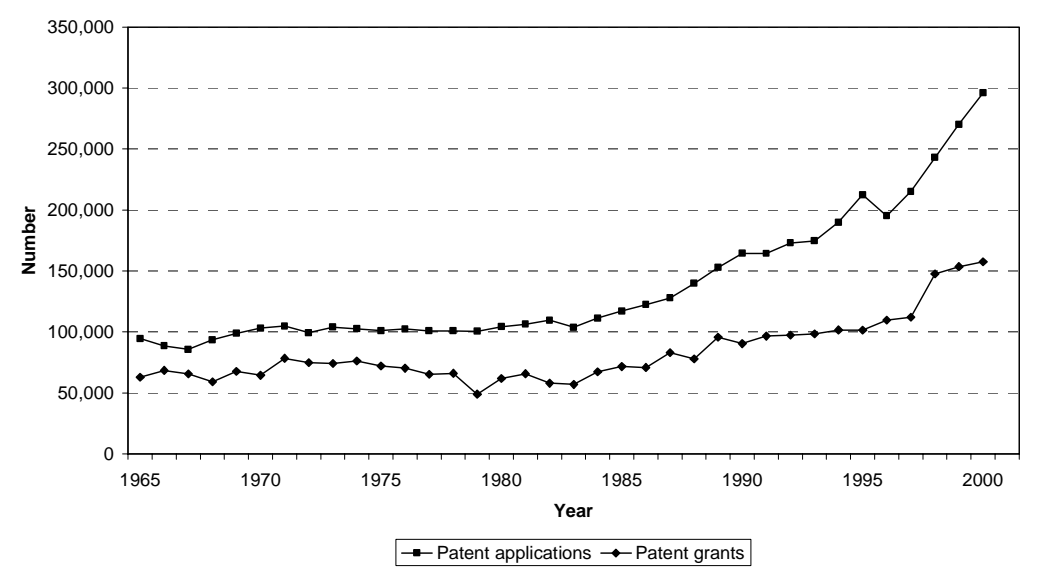

Figure 1. US Patent and Trademark Office utility patents 1965-2000 


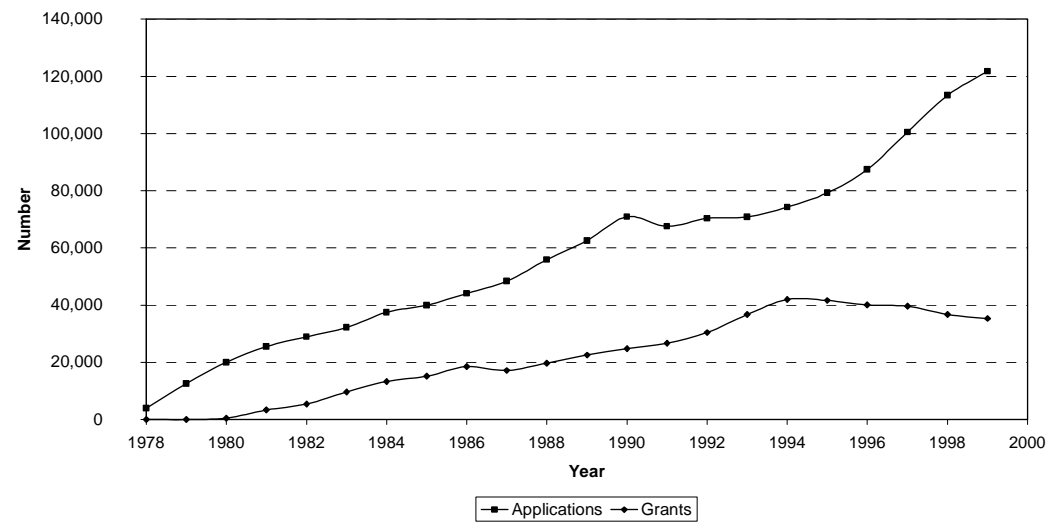

Figure 2. European Patent Office and EPO/PCT (Patent Co-operation Treaty) patents 1978-1999

policy makers and academics are concerned with increasing litigation costs, including indirect costs, which may distort the innovative behaviour of small companies. As John Barton (2000) put it, there is a problem when "the number of intellectual property lawyers is growing faster than the number of researchers". This is exactly what has happened in the USA, while similar trends in Europe show that it is no longer a purely American problem.

This problem is not new, of course, as the following comment by a concerned industrialist in 1865 shows: ${ }^{2}$

"In the manufacture with which I am connected - the sugar trade - there are somewhere like 300 or 400 patents. Now, how are we to know all these 400 patents? How are we to manage continually, in the natural process of making improvements in manufacture, to know which of these patents we are at any time conflicting with? So far as I know, we are not violating any patent; but really, if we are to be exceedingly earnest in the question, probably we would require to have a highly paid clerk in London continually analysing the various patents; and every year, by the multiplication of patents, this difficulty is becoming more formidable."

We can, however, consider that the extent of the problem has grown substantially in recent years.

Blockage and anticommons trap The following two cases are particularly indicative of the problem of anticommons (a risk of underuse of resources) as it might occur in the knowledge economy (Heller and Eisenberg, 1998).

The first blockage results from the fact that knowledge is fragmented and rights are granted to portions of knowledge before the corresponding product is identified, whereas previously it was the genes corresponding to products that were patented, for instance, therapeutic proteins, diagnostic tests. The proliferation of patents on fragments of genes owned by different agents hugely complicates the co-ordination required by an agent interested in developing a product. In particular, if the acquisition of all necessary licences is too complicated or expensive, the product will never materialise.

A second blockage results from procedures known as 'reachthrough licence agreements', which provide the patent holder with rights over future discoveries. These rights may consist of the payment of royalties on sales, of licences on future discoveries, or of a priority option for obtaining licences. The system was initially designed to enable researchers with limited financial resources to use a patented discovery and to pay only if the research produced results.

In the end, however, this kind of system gives the owners of first patents the right to be present at all stages of subsequent developments, even if they did not contribute to them. Once again, there is a risk of under-utilisation of certain discoveries because of situations in which the rights of those concerned become entangled.

Certain situations in the domain of information technology also pose this type of problem.

Is the anticommons regime described a transition, or does it signal a tragedy? Theoretically, we can hope for the creation of appropriate institutions to help agents co-ordinate the trading of licences. Also theoretically, collective learning can lead to real decreases in transaction costs. In practice, however, it is difficult to see how mechanisms of natural correction could appear and put an end to these deadlock situations.

There is a huge degree of heterogeneity among actors, and transaction costs are enormous for those wanting to group together rights in order to recompose fragmented knowledge. Even worse, cognitive biases cause everyone to overestimate the probability of their own patent being a miracle patent, which leads everyone to want more than the probable value of the asset in question (Heller and Eisenberg, 1998).

Privatisation of science All studies indicate that the evolution towards the privatisation of science represents a real risk of an irremediable alteration of modes of co-operation and sharing of knowledge in 


\section{All studies indicate that the evolution towards the privatisation of science represents a real risk of an irremediable alteration of modes of co-operation and sharing of knowledge in the domain of basic research}

the domain of basic research. Restricted access to knowledge and the retention of knowledge produced by universities comes in several forms, for instance, delayed or partial publication and communication, secrecy, and patents. The exclusive licence is a significant form, that is, new knowledge is sold exclusively to one firm. When there is nothing left but exclusive bilateral contracts between university laboratories and firms, we have forms of quasiintegration, which undermine the domain of open knowledge.

Mowery et al (1999) study the impact of American laws authorising universities to grant exclusive licences on the results of research financed by public funds, especially the Bayh-Dole Act. These laws aim to solve the problem of 'post-invention' costs and risks in taking a new invention out of the laboratory and developing it into a successful commercial product. Firms would be unwilling to support these costs without some assurance of protection from competition. Patents and exclusive licensing thus facilitate the transfer of new technology to the private sector by providing exclusive rights to preserve the profit incentives of innovating firms.

However, by only focusing on exclusive licensing, these laws are based on a narrow view of the channels through which public research interacts with industry. In reality, these channels are multiple (publication, conferences, consultancy, training, expertise) and all contribute to the transfer of knowledge, while the incentives created by such legislation only promote one channel (patenting and licences), at the risk of blocking the others. The authors' conclusion is unambiguous (Mowery et al, 1998, page 29):

\footnotetext{
"The Bayh-Dole Act and the related activities of US universities in seeking out industrial funding for collaborative R\&D have considerable potential to increase the 'excludability' of academic research results and to reduce the 'knowledge distribution' capabilities of university research."
}

Institutional diversity in danger Threats against the diversity of institutional arrangements are a cause for concern. Traditionally, IPRs are considered to be one of the incentive structures society employs to encourage innovative effort. They co-exist with other incentive structures, each of which has costs and benefits as well as a degree of complementarity. The new view is that IPRs are the only means by which to commodify the intangible capital represented by knowledge. They should therefore serve as a common currency or 'yardstick' for measuring the output of activities devoted to knowledge generation and the basis for markets in knowledge exchange.

In a recent book (Foray, 2004), I analysed such diversity as being important on the grounds that each institution fulfils specific functions, and strong complementarities exist between them; however, the space for public research (procurement and patronage) is shrinking, and functions that were assumed by open science are no longer assumed at the same level. This is a problem, not only for the survival of open science per se, but also for the sustainability of the patent system as a whole. Excessive privatisation may undermine the long-term interests of industry itself, which will benefit from less public knowledge, less training and screening externalities.

Finally, the scenario of a pure functional substitution (the private sector would simply carry out the functions that were formerly assumed by the public sector) is incorrect. We know that private companies will never fund the same type of basic research that the public sector abandons. Similarly, market-based institutions could satisfy the need for scientific training only very partially.

As argued by Cohen et al (1998), there are several reasons why spillovers from the downstream $R \& D$ conducted by firms engaged in basic research is not likely to entirely replace the information flows that were initially blocked. First, firms will attempt to restrict spillovers to retain proprietary advantage. Second, there will typically be considerable lags between the time when the firm receives the valuable information and the time when information spills over to other firms. Economic studies on the US model reveal a degree of concern. One of the conclusions presented by Cockburn and Henderson (1997, page 30) is that:
"policies which weaken these institutions (of open science), make public sector researchers more market-oriented, or redistribute rents through efforts to increase the appropriability of public research through restrictions in the ways in which public and private sectors work with each other, may therefore be counter- productive in the long run."

This is a strong conclusion that prompts us to examine this new model carefully without being blinded by the brilliance of its undeniable short-term performance. 


\section{Solving the long-term problems}

The issue is certainly not to abolish the patent system; rather, it is to make corrections and improvements at the margin capable of bringing about a certain equilibrium in some instances and securing enduring and dynamic innovation processes. We can list three classes of solutions to the various problems developed below.

\section{Facilitate access to private knowledge}

Mechanisms are devised to support the rapid dissemination and free exploitation of private knowledge in certain circumstances or for certain classes of economic agents. There are three main mechanisms:

- Compulsory licensing (compulsory diffusion of private knowledge in the general interest): while the very idea of a compulsory licence was viewed as an insult to the notion of property (since a basic right - that of not selling - is alienated), this practice is tending to take over and to spread to unexceptional circumstances. While most compulsory licences are applied for in the general interest (consider the struggle between South Africa and the major pharmaceutical multinationals), it tends to become a last resort in the field of competition policy when the refusal to grant a licence can be interpreted as abuse of a dominant position.

- Patent buyout: the state or an international foundation purchasing patents to return them to the public domain. The historical case traditionally drawn on to illustrate this mechanism is that of Daguerre, the inventor of photography, who neither exploited his invention nor sold it for the price he wanted. In 1839, the French Government purchased the patent and put the rights to Daguerre's invention in the public domain. The invention was developed very quickly!

- Price discrimination: Ramsey's pricing rule suggests price discrimination between users whose demands are inelastic and those for whom the quantity purchased is extremely price-sensitive. The former category of buyer will therefore bear high prices without curtailing the quantity of goods purchased, whereas the low prices offered to those in the second category, for instance, scholars and university-based researchers, will spare them the burden of economic welfare reducing cutbacks in their use of the good. The clause of fair use for research or educational purposes is an interpretation of this rule.

The well-known problem involved in compulsory licensing and patent-buyout schemes has to do with the valuation of the invention and the likelihood of burdensome legal and administrative expenses that makes these schemes second-best solutions.
Navigating the patent thicket.

Cross-licensing mechanisms offer a classical solution to the anticommons trap. Processes of learning about the trading of rights and systems of mutual concession can occur, for instance, within a consortium. This may keep transaction costs at tolerable levels and thus favour the regulation of the anticommon regime to a certain extent; however, it is a solution that can work only with a limited number of companies. In that respect, the rapid growth of new kinds of firms does caution against overconfidence in relation to overcoming anticommons problems. For example, the computer hardware industry had few problems with its cross-licensing arrangements until new kinds of semiconductor companies emerged.

\section{Actions directed at patent office practices}

If patent requirements are to be strictly enforced, a great deal of action must be taken as regards the patent office (utility requirement, non-obviousness, patent scope). Policy-makers ought to launch programmes to convince patent officers of the critical need to create initial endowments of property rights that are more coherent in so far as they respect the indivisibility of goods (avoiding the anticommons trap).

We should note, however, that hybrid and complex objects, for instance, genes, DNA sequences, software and databases, generate numerous uncertainties about the appropriate intellectual property policy related to them, rendering the tasks of patent offices very difficult. It is difficult to provide unambiguous, clear answers to the question of whether these new objects should be privately appropriated and, if so, what class of IPR should be used. We are now living in a period in which these new objects are being put to the test.

Under this kind of circumstance of great uncertainty, it might be useful to think about the creation of new categories of intellectual property, such as the 'common good' - a category that would match those situations in which 'we don't know', that is, society requires time to consider the legal status of the new object while the economy requires some measure of legal certainty to proceed with $R \& D$ investments. In this respect, lawyers think that certain new complex and hybrid objects, such as genes, do not fit in the usual categories of private-public goods. Instead, they propose to work on a new category: the common good.

Under a common good regime, innovation defies patrimonial and commercial appropriation. The private company that is in possession of it for industrial exploitation is not the owner of the good; rather, it serves as a sort of manager. Such a regime would allow for the emergence of an industry while avoiding private and exclusive rights. 


\section{Beyond intellectual property}

In contexts in which reliance on such mitigating devices is not feasible or not very effective, the alternative mechanisms for solving the public good problem based on public property may be superior to intellectual property rights as a means of stimulating innovation.

\section{Concluding remarks}

The intellectual property institution is in flux. It is shifting away from a patent system preserving the right of the inventor to 'say no' (to refuse access and to keep the knowledge unexploited) to a system promoting the right of systematic access while preserving a right for the inventor to be remunerated. The increasing importance in policy discussions concerning compulsory licensing (beginning to be used not only in areas of public health and security, but also for competition policy reasons), the new policy interest in price discrimination schemes, and the abundant literature on various ways to obtain a 'freedom to operate' by bypassing or ignoring intellectual property, signal just such an evolution.

How far can the system go, and to what extent can the provision of this kind of tool assist in the solution of problems of knowledge access? Are these mechanisms sufficiently strong and enforced in domains where 'essential human rights' are at stake (health, education, food)? Is, for instance, a system of compulsory licensing the solution to the problem raised by the broad patents covering diagnostic tests for breast cancer, as well as other similar problems in the healthcare and pharmaceutical areas?

In such a changing institutional context, the European challenge is twofold as regards adapting and transforming its patent system.

- Creating a more effective system is the first challenge. This ought to be brought about through the creation of a true European Community patent that supports common procedures for applying and granting patents, as well as enforcing property rights by significantly lowering the levels of legal uncertainty and costs.

- Learning from American experiments (and perhaps mistakes) is the second challenge. This involves setting a different trajectory regarding institution design as related to innovation and knowledge creation and distribution. Indeed, there are some doubts as to the fact whether, in the age of the knowledge economy, the new equilibrium established in the USA (with intensive patenting activities, large amounts of cross-licensing, aggressive patent enforcement strategies and privatisation of some basic research activities) is better than the preceding one, which was characterised by a moderate level of patenting activities, firms allowing diffusion of their own knowledge in return for low cost absorption of other's knowledge, and a large public research domain. The latter appears to be a system with lower transaction costs, while the former does not seem distinctly superior in terms of knowledge production. The extent to which Europe can achieve the latter equilibrium without hampering its competitive position remains an open question.

\section{Notes}

1. Prior art search is looking for antecedents of the innovation.

2. Macfie, R A, quoted in George W Hastings (editor) (1865), "Is the granting of patents for inventions conducive to the interests of trade?", Transactions of the National Association for the Promotion of Social Science, pages 661-665. Thanks to Bronwyn Hall for drawing my attention to this quotation.

\section{References}

Arora, A, A Fosfuri and A Gambardella (2001), Markets for Technology (MIT Press, Cambridge MA).

Barton, J (2000), "Reforming the patent system", Science, 287(5460), pages 19330-1934.

Cockburn, I, and R Henderson (1997), "Public-private interaction and the productivity of pharmaceutical research", WP series, \#6018, National Bureau of Economic Research, Cambridge.

Cohen, W, R Florida, L Randazzese and J Walsh (1998), "Industry and the academy: uneasy partners in the cause of technological advance", in R Noll (editor), Challenge to the Research University (Brookings Institution, Washington DC) pages 171-179.

Foray, D (2004), The Economics of Knowledge (MIT Press, Cambridge MA).

Hall, B (2001), "The global nature of intellectual property: discussion”, draft, Department of Economics, University of California at Berkeley, May.

Hall, B, and R Ziedonis (2001), "The patent paradox revisited: an empirical study of patenting in the US semiconductor industry, 1979-1995", Rand Journal of Economics, 32(1), pages 101128

Heller, M, and R Eisenberg (1998), "Can patents deter innovation? The anticommons in biomedical research," Science, 280, pages 698-701.

Horward, A (2002), "The Community patent", in Patinnova (editor), Innovation/SMEs Programme (EC, DG-Enterprise, Luxembourg) pages 123-138.

Jaffe, A (2000), "The US patent system in transition: policy innovation and the innovation process", Research Policy, 29, pages 531-557.

MERIT (2000), Innovation policy in a knowledge-based economy, a publication from the Innovation/SMEs programme; DGEnterprise, EUR 17023 (European Commission, Luxembourg).

Mowery, D C, R R Nelson, B Sampat and A A Ziedonis (1999), "The effects of the Bayh-Dole Act on US university research and technology transfer: an analysis of data from Columbia University, the University of California, and Stanford University", Working Paper, Kennedy School of Government, Harvard University, Cambridge MA.

Pooley, J (2002), "Changing times for the US patent system", Business Perspectives, Summer/Fall, available at <http://bber. memphis.edu/PDF/Summer2001.pdf>. 